\title{
QUO VADIS, RUSSIA? ON THE COUNTRY'S RECENT APPROACH TOWARDS IMPLEMENTING JUDGMENTS OF THE EUROPEAN COURT OF HUMAN RIGHTS
}

\begin{abstract}
The article analyses the recent approach of the Russian Constitutional Court towards execution of judgments of the European Court of Human Rights, with special focus on its most recent jurisprudence, including the 2017 verdict related to the case of OAO Neftyanaya Kompaniya Yukos v. Russia. Subsequently, it discusses whether such an approach is yet another example of "judicial dialogue" between domestic and international courts, or whether it is of more specific character, aiming at undermining the general authority of the ECHR.
\end{abstract}

\section{Keywords}

Russian Constitutional Court - judicial dialogue - European Court of Human Rights domestic and international law - Yukos case - OAO Neftyanaya Kompaniya Yukos v. Russia

* M.A. in law and history, is preparing doctoral thesis in migration law at Faculty of Law and Administration, Jagiellonian University, e-mail: michal.gorski@gmail.com. The author wishes to thank Prof. Michał Kowalski for his continuous support as well as Dr Paweł Marcisz for his valuable remarks on an earlier draft of the paper. Despite all the assistance, the responsibility for any omissions and errors lies solely with the author. 


\section{INTRODUCTION}

On 19 January 2017 the Constitutional Court of the Russian Federation (hereinafter: RCC) delivered a decision ${ }^{1}$ regarding execution of the judgment of the European Court of Human Rights (hereinafter: ECtHR or Strasbourg Court), which the latter passed in the case of OAO Neftyanaya Kompaniya Yukos $v$. Russia ${ }^{2}$. It was another ruling of the RCC delivered pursuant to the recently introduced procedure "regarding the possibility of enforcing decisions of an inter-state human rights body" (see below), but the first in which it stated that the individual measure indicated by the Strasbourg Court might not be implemented by the Russian authorities, thus for the first time explicitly making the ECtHR judgment non-executable in full accordance with the domestic law. The article aims at analysing the recent approach of the Russian Constitutional Court towards execution of judgments of the European Court of Human Rights. It further discusses whether such an approach is just another example of 'judicial dialogue' between domestic and international courts, or whether it is of more specific character, aiming at undermining the general authority of the ECtHR.

\section{YUKOS CASE}

Before I elaborate more on this matter, it is worthwhile summarizing the circumstances of the case of OAO Neftyanaya Kompaniya Yukos v. Russia. The ECtHR in its principal judgment on merits $^{3}$ found violation

${ }^{1}$ Postanovlenie Konstitutsionnogo Suda Rossiyskoy Federatsii (Decision of the RCC), dated 19 January 2017, no. 1-П/2017, “Rossiyskaya gazeta”, No. 24 (03 February 2017); English translation available at the RCC's official website: http:/ /www.ksrf.ru/ en/Decision/Judgments/Documents/2017_January_19_1-P.pdf.

${ }^{2}$ ECtHR, OAO Neftyanaya Kompaniya Yukos v. Russia (14902/04), judgment of 31 July 2014, this and other cited ECtHR's rulings available at http:/ / www.echr.coe.int;

${ }^{3}$ ECtHR, OAO Neftyanaya Kompaniya Yukos v. Russia (14902/04), judgment of 20 September 2011. For in-depth analysis of the Yukos case see e.g. E. de Brabandere, OAO Neftyanaya Kompaniya Yukos v. Russia (Eur. Ct. H.R.), "International Legal Materials" 2016, vol. 55, issue 3, pp. 474-495; L.A. Groen, The 'Iukos Affair'. The Russian Judiciary and 
of Article 1 of Protocol no. 1 to the European Convention of Human Rights (hereinafter: the Convention) because of the unlawfulness of the imposition and calculation of penalties regarding the company's tax assessments for years 2000-2001, as well as the disproportionality of the enforcement proceedings. Also, paras. 1 and 3 of Article 6 of the Convention were breached, as far as the 2000 tax assessment proceedings against the company were concerned (insufficient time for preparation before the lower courts) ${ }^{4}$. However, Yukos's victory was only partial, as the ECtHR did not find violation of Article 1 of Protocol no. 1 to the Convention regarding other aspects of tax assessments, as well as Article 14 in conjunction with Article 1 of Protocol No. 1, as for the alleged different treatment in comparison with other companies. Most importantly, the Strasbourg Court also did not agree with the applicant's arguments on violation of Article 18 of the Convention in conjunction with Article 1 of Protocol No. 1, as it was not proven that the enforcement proceedings had in fact constituted disguised expropriation of the company's property and the intentional destruction of the company itself.

The ECtHR left the question concerning amount of compensation to be awarded for the future, inviting the parties to submit their written observations on the matter or to reach an out of court agreement. Three years later, on 31 July 2014, the ECtHR delivered its verdict regarding the just compensation with the total amount of $1,866,104,634$ euros to be paid to the company's shareholders and their legal successors. Despite the fact that it constituted only $2 \%$ of the sum requested by the applicant, it was nevertheless a definite record as for the amount of compensation awarded ever by the ECtHR. The judgment also imposed an obligation for Russian authorities to produce a comprehensive plan for distribution of the award of just satisfaction, which has never been fulfilled.

the European Court of Human Rights, "Review of Central and East European Law" 2013, vol. 38, issue 1, 77-108; Paul B. Stephan, "Taxation and Expropriation - the Destruction of the Yukos Oil Empire", 35(1) "Houston Journal of International Law" (2013), pp. 2-52.

${ }^{4}$ Because of that, I will not elaborate on political aspects related to the case (as well as to the case of Mikhail Khodorkovskyi and his business partners, see below), nor on questions regarding the independence of the Russian judiciary, even though both these issues still raise controversies. See Laurence A. Groen, supra note 3, pp. 79-81; Paul B. Stephan, supra note 3, p. 51. 
The case was obviously related to Mikhail Khodorkovski, a former Chief Executive Officer and main shareholder of Yukos, a political opponent of President Vladimir Putin, sentenced in two trials in total to 14 years in penal colonies. ${ }^{5}$ He also took the case to the ECtHR for himself, which on 31 May 2011 found eight violations of several articles of the Convention ${ }^{6}$, but rejected declaring a violation of Article $18^{7}$, a point which the Russian authorities described as their victory. ${ }^{8}$ Khodorkovski was eventually pardoned by V. Putin in 2013 and immediately left for Switzerland.

It is also worth mentioning that the former Yukos's shareholders took several legal actions against the Russian state or the state-owned company Rosneft (which took over most of Yukos's assets) abroad. The proceedings that especially attracted public interest were those before the Permanent Court of Arbitration under the Energy Charter Treaty. In 2014 the latter delivered the decision, awarding more than 50 billion (sic!) dollars to the claimants on Yukos's side. ${ }^{9}$

\section{RUSSIA'S RECENT 'SOVEREIGNTY APPROACH' TOWARDS ECTHR}

In the meantime, the Russian authorities took steps aimed at institutionalizing and strengthening the doctrine of sovereignty, which

${ }^{5}$ Similar judgment was delivered also against Khodorkovskyi's business partner, Platon Lebedev. Criminal proceedings were brought also against their (as well as the company's) seriously-ill lawyer, Vasilii Aleksanian, but were dropped because of the statute of limitations. see L. A. Groen, supra note 3, pp. 87-90.

${ }^{6}$ ECtHR, Khodorkovskiy v. Russia (3829/04), judgment of 31 May 2011;

7 Article 18 of the ECHR (Limitation on use of restrictions on rights): The restrictions permitted under this Convention to the said rights and freedoms shall not be applied for any purpose other than those for which they have been prescribed.

8 Another application by Khodorkovskyi regarding the Russian authorities' subsequent actions against him also resulted in finding violation of several norms of the Convention law, but, again, without Article 18. ECtHR, Khodorkovskiy v. Russia (no. 2) (11082/06), judgment of 25 July 2013.

${ }^{9}$ For more on this topic see: Marcin Kałdunski, Some Reflections on Arbitration in the Yukos v. The Russian Federation Case, "Comparative Law Review" 2014, issue 18, pp. 141-167. However, the PCA's judgment was recently quashed by the District Court of The Hague 
emphasises the supremacy of the Constitution of the Russian Federation ${ }^{10}$ over international law, including the European Convention of Human Rights and, especially, ECtHR's judgments delivered on its basis ${ }^{11}$. Soon after the Strasbourg Court's 2014 judgment regarding the sum of just satisfaction for Yukos's shareholders, a group of deputies of the State Duma requested the RCC to rule upon the constitutionality of the Federal Law on the Accession of the Russian Federation to the European Convention on Human Rights ${ }^{12}$ and of other provisions of Russian law related to enforcement of judgments of the ECtHR. In its judgment delivered on 14 July $2015^{13}$, the RCC came to conclusion that the provisions in question do not contradict the Russian Constitution. However, the RCC reaffirmed the supreme position of the latter. It also stressed that this supremacy results in the obligation of lower courts to petition the RCC, whenever they (re)examine a case in which the ECtHR had previously found federal legislation violating the Convention, about the conformity of this legislation with the Russian Constitution ${ }^{14}$. Even more importantly, the RCC recognized the right of the executive power (the President and the Government) to petition the RCC should they come to the conclusion that implementation of an ECtHR's judgment might

on formal reasons (non-ratification of the Treaty by Russia). See Neil Buckley, Russia wins legal victory over Yukos damages, "Financial Times" (20 April 2016), available at: https:/ / www.ft.com/content/2a23a352-06ce-11e6-a70d-4e39ac32c284. The latter Hague court's verdict is not final.

${ }^{10}$ Konstitutsiya Rossiyskoy Federatsii (Constitution of the Russian Federation), Rossiyskaya gazeta (25 December 1993), No. 237 as amended; unofficial English translation available at: http://www.constitution.ru/en/10003000-01.htm.

11 The sovereignty doctrine is based on Article 15 par. 1 of the Constitution, which reads: „The Constitution of the Russian Federation shall have the supreme juridical force, direct action and shall be used on the whole territory of the Russian Federation".

12 Zakon «O ratifikatsii Konventsii o zashchite prav cheloveka i osnovnykh svobod i Protokolov k ney», "Rossiyskaya gazeta”, No. 67, (7 April 1998).

${ }_{13}$ Postanovlenie Konstitutsionnogo Suda Rossiyskoy Federatsii (Decision of the RCC), dated 14 July 2015, 21-П/2015, "Rossiyskaya gazeta", No. 163, 27.07.2015.

14 This point was already made by the RCC in its previous verdict regarding the case of K. Markin. See Postanovlenie Konstitutsionnogo Suda Rossiyskoy Federatsii (Decision of the RCC), dated 6 December 2013, No. 27-П/2013, "Rossiyskaya gazeta", No. 285, 18 December 2013, English translation available at: http://www.ksrf.ru/en/ Decision/Pages/ViewItem.aspx?ParamId=125 which will be described further below. 
stand in contradiction with the Constitution. It was stated explicitly that, if the RCC agrees with the petitioner, in such case the ECtHR's judgment is not to be executed. ${ }^{15}$

The law in question was passed by the State Duma in December 2015. ${ }^{16}$ A whole new chapter to the Law on the Constitutional Court of the Russian Federation was added, named "Examination of cases regarding the possibility of enforcing decisions of an inter-state human rights body"17. In line with the recent RCC's judgment, it provided the President as well as the Government with a procedure for petitioning the RCC about the constitutionality of execution of any judgment of an international human rights judicial body delivered against the state (Article 105 section 2 of the amended Law). Hence, pursuant to the newly adopted Article $104^{4}$ section 2 and Article 106 section 2, in case the RCC decides that implementation of a judgment of the ECtHR would contradict the Constitution, no measures of executions may be taken in the Russian Federation. The new law became a source of concern, especially within the Council of Europe. The Venice Commission in its report ${ }^{18}$ emphasised the obligation stemming from Article 46 of the Convention and stated inter alia that the RCC ought not to have been given the power to declare an international decision generally "non-executable", and thus urged the repeal of the afore-mentioned Articles $104^{4}$ par. 2 and Article 106 section 2 of the amended Federal Constitutional Law on the Constitutional

${ }^{15}$ For more on this judgment see L. Mälksoo, Russia's Constitutional Court Defies the European Court of Human Rights: Constitutional Court of the Russian Federation Judgment of 14 July 2015, No 21-П/2015, European Constitutional Law Review 2015, vol. 12, issue 2, pp. 377-395; M. Smirnova, Russian Constitutional Court Affirms Russian Constitution's Supremacy over ECtHR Decisions, "UK Constitution Law Blog" (17 July 2015), available at: https://ukconstitutionallaw.org/.

${ }^{16}$ Federal'nyy Konstitutsionnyy Zakon O Vnesenii Izmeneniy v Federal'nyy Konstitutsionnyy Zakon "O Konstitutsionnom Sude Rossiyskoy Federatsii”, dated 14 December 2015, No. 7-ФK3, Rossiyskaya gazeta, No. 284, (16.12.2015); English translation available at the Venice Commission's website: http://www.venice.coe.int/webforms/documents/ default.aspx?pdffile=CDL-REF(2016)006-e.

17 Rus. "Rassmotrenie Del o Vozmozhnosti Ispolneniya Resheniy Mezhgosudarstvennogo Organa po Zashchite Prav i Svobod Cheloveka".

18 European Commission for Democracy through Law (Venice Commission), Russian Federation - Final Opinion on the Amendments to the Federal Constitutional Law on the Constitutional Court, no. 832/2015 (CDL-AD(2016)016), adopted on 10-11 June 
Court of the Russian Federation. The report suggested that the RCC could instead assess the compatibility with the Russian constitution of a given measure of enforcement proposed by the executive authorities, with the exception of a modality indicated specifically by the ECtHR. Accordingly, the Commission emphasised that the RCC should not have been furnished with the power to assess the constitutionality of an order to pay just satisfaction ${ }^{19}$, as if its members had already anticipated which ECtHR's case could be brought to the RCC for a constitutionality review.

The first case examined by the RCC pursuant to the new procedure was actually an earlier one than that of Yukos, i.e. Anchugov and Gladkov v. Russian Federation ${ }^{20}$. In the judgment of 4 July $2013^{21}$, the ECtHR found that the absolute ban on voting rights of prisoners, provided for in Article 32 section 3 of the Russian Constitution, stood in violation of Article 3 of Protocol No.1 to the Convention (right to free elections). ${ }^{22}$ In its verdict, the RCC again emphasised the supremacy of the Russian Constitution and concluded that in any case voting rights might not be granted to S.B. Anchugov and V.M. Gladkov because of the gravity of their crimes (including murders, point 7 of the RCC's verdict). What is more important, the court also stated that because of the unequivocal wording of the aforementioned Article 32 sect. 3 of the Russian Constitution, voting rights might not be also given to anyone serving a prison sentence, thus rejecting the ECtHR's suggestion regarding other interpretations of this article (point 4.4 of the RCC's verdict). Nevertheless, the RCC insisted that a different general measure may suffice for implementation of the ECtHR's verdict as, according to the statistics available, less than $10 \%$ of

2016, available at: http://www.venice.coe.int/webforms/documents/default.aspx? pdffile $=$ CDL-AD(2016)016-e.

19 Ibid., point 28.

${ }^{20}$ Postanovlenie Konstitutsionnogo Suda Rossiyskoy Federatsii (Decision of the RCC), dated 19 April 2016, 12-П/2016, "Rossiyskaya gazeta", No. 95, 05.05.2016, English translation available at: http:/ / www.ksrf.ru/en/Decision/Judgments/Documents/2016_ April_19_12-P.pdf.

${ }^{21}$ ECtHR, Anchugov and Gladkov v. Russian Federation (11157/04 and 15162/05), judgment of 4 July 2013.

${ }^{22}$ Pursuant to the Article 32 sect. 3 of the Russian Constitution, "deprived of the right to elect and be elected shall be citizens recognized by court as legally unfit, as well as citizens kept in places of deprivation of liberty by a court sentence". 
persons who had committed minor crimes (with maximum deprivation of liberty less than 3 years), were in fact sentenced to prison (points 5.1-5.3 of the RCC's verdict). This, in the RCC's opinion, constituted a proof of an individualized approach towards depriving offenders of voting rights. The Russian judges also suggested that the authorities, "realizing the principle of humanism in the criminal law", might introduce alterations to the Criminal Executive Code in order to define some forms of restriction of liberty other than prison sentence (e.g. correctional institutions) as not "depriving of liberty" in the meaning of Article 32 section 3 of the Russian Constitution (point 5.5).

The RCC verdict meant the de facto rejection of the ECtHR's position regarding the conformity of the current legal Russian legislation and practice with Article 3 of Protocol No. 1 to the Convention. However, it was not openly confrontational - firstly, because the ECtHR had not indicated any individual measures towards the applicants, so even explicit rejection of granting them voting rights was not in contradiction with the Strasbourg Court's judgment. Secondly, the ECtHR did not specify any general measures, leaving this question to the respondent state under supervision of the Committee of Ministers. In that respect the RCC emphasised that the Strasbourg Court's judgment might be implemented by general measures already existing in the Russian legal system (or with some changes of the Criminal Executive Code) - however odd it sounded, bearing in mind that virtually nothing had changed since delivering the judgment by the ECtHR three years earlier in this matter. Lastly, Russia was not the first country reluctant to implement the Strasbourg Court's judgment regarding the voting rights of prisoners, as a similar problem concerned the United Kingdom, which will be discussed further below.

The second ECtHR's judgment adopted by the RCC pursuant to the new procedure was OAO Neftyanaya Kompaniya Yukos v. Russia. The RF Minister of Justice requested a review of the constitutionality of the implementation of the ECtHR's judgment of 31 July 2014 in respect of the obligation to pay the awarded satisfaction to the company's former shareholders. This time the Russian judges left no space for flexibility they ruled unequivocally that execution of the ruling in question would stand in contradiction with the Russian Constitution. They again started from the sovereignty principle and subsequently, referring to its latest 
jurisprudence, they emphasized that the RCC might also rule upon whether the ECtHR's interpretation of the Convention had been in conformity with the Vienna Convention on the Law of Treaties, especially article 31 sect. $1^{23}$. (point 2 of the RCC's judgment). Characteristically, this time the Russian judges did not even mention the "several years of experience of constructive cooperation and mutually respectful dialogue", as they did in the previous, more "conciliatory" judgment regarding the case of Anchugov and Gladkov v. Russian Federation. Subsequently, after elaborating on Yukos's alleged tax evasion techniques, Russian law and jurisprudence regarding tax law, as well as rejecting the ECtHR's position on the status of victims of Yukos's former shareholders and their legal successors, the RCC came to the conclusion that

\begin{abstract}
"payment of such a huge monetary sum, imposed by the European Court of Human Rights, to former shareholders of a company having built illegal schemes of evasion of taxation, their heirs and legal successors from the budget system, which was regularly not receiving from it in due amount enormous tax payments, necessary inter alia for the fulfilment of public obligations for the benefit of all citizens, getting over a financial and economic crisis, in itself contradicts constitutional principles of equality and justice in tax relations (Article 17, Section 3; Article 19, Sections 1 and 2; Article 55, Sections 2 and 3; Article 57 of the Constitution of the Russian Federation)" (point 4.5. of the RCC's judgment, original translation).
\end{abstract}

It should be noted that even though the review concerned the 2014 ECtHR's judgment on just satisfaction, the RCC in fact referred in many aspects to the 2011 Strasbourg Court's verdict on merits, criticizing its non-acceptance of Russian law and jurisprudence regarding the statute of limitation of tax offences as well as conclusions on enforcement fees (points 4-5 of the RCC's judgment). In this regard the RCC's judgment may be regarded as ultra vires.

One judge (V.G. Yaroslavtsev) issued a dissenting opinion to the RCC's decision $^{24}$, arguing that, (1) the whole case concerned statutory

${ }^{23}$ Article 31 sect. 1 of the Vienna Convention on the Law of Treaties: "A treaty shall be interpreted in good faith in accordance with the ordinary meaning to be given to the terms of the treaty in their context and in the light of its object and purpose".

${ }^{24}$ Osoboe mnenie sud'i Konstitutsionnogo Suda Rossiyskoy Federatsii V.G. Yaroslav- 
(i.e. tax) and not constitutional law, (2) one of the reasons of finding a violation of the Convention was the 2005 judgment of the RCC on extending retrospectively the statute of limitations of then Russian tax law, and thus, the RCC's current ruling would stand against the nemo iudex in propria causa rule, (3) after the 2011 ECtHR's judgment the Russian Government introduced steps towards its implementation (proposals sent to the Committee of Ministers). Another judge, K.V. Aranovsky, in his very peculiar opinion argued that the ECtHR's judgment did not in fact constitute a judgment, as the company's shareholders did not take part in the proceedings and, as a result, were allegedly deprived of procedural rights, including the right to a hearing. Thus, according to the judge, the ECtHR's (allegedly non-)judgment could not be implemented ${ }^{25}$. Characteristically, the President of the RCC Valeryy Zorkin did not issue a separate opinion, even though during the 2010 conference $^{26}$ he stated that:

"I want to unequivocally emphasize that in no way do I question the necessity of execution of the European Court's decisions, no matter how some observers try to interpret and distort my words. ECtHR's decisions should be executed unconditionally - whether we are talking about payment of compensation or restoration of the violated rights of the applicant in a particular case" ${ }^{27}$

tseva (Separate opinion of the judge of the Constitutional Court of the Russian Federation V.G. Yaroslavtsev), annexed to the judgment.

${ }^{25}$ Mnenie sud'i Konstitutsionnogo Suda Rossiyskoy Federatsii K.V.Aranovskogo (Opinion of the judge of the Constitutional Court of the Russian Federation K.V. Aranovsky, points 2.1-2.8.

${ }^{26}$ Valeriyy D. Zorkin, “Dialog Konstitutsionnogo Suda Rossiyskoy Federatsii i Yevropeyskogo Suda po pravam cheloveka v kontekste konstitutsionnogo pravoporyadka" (Dialogue of the Constitutional Court and the European Court of Human Rights in the context of the constitutional order), Doklad na XIII Mezhdunarodnom Forume po konstitutsionnomu pravosudiyu (report at the XIII International Forum on Constitutional Justice), Sankt Petersburg, 18-20 November 2010, available at: http:/ /www.ksrf.ru/ru/ News/Speech/Pages/ViewItem.aspx?ParamId=39.

${ }^{27}$ Translation by the author, bolding in the original text. 


\section{PROBLem OF NON-EXECUTION OF THE ECTHR'S JUDGMENTS IN OTHER COE COUNTRIES}

Although the human rights protection system under the European Convention of Human Rights is regarded as the most effective in international $l a w^{28}$, it definitely does not mean that execution of ECtHR's judgments proceeds without problems, even as regards individual measures concerning the payment of the just satisfaction awarded ${ }^{29}$. Interestingly, notwithstanding the constant tensions between Russia and the Council of Europe from the very moment of ratification of the Convention by Russia ${ }^{30}$, until the Yukos case the country was reported rather for not taking any execution measures other than payment of compensation. It was described as a "partial" or "à la carte" implementation ${ }^{31}$. Additionally, it should be noted that also some serious legal reforms were introduced in Russia as general measures of implementing ECtHR's judgments, e.g. a remedy against non-enforcement or delayed enforcement of domestic decision ${ }^{32}$.

Non-execution of ECtHR's judgments is a point of particular concern for the Council of Europe institutions and was a subject of numerous

${ }^{28}$ H. Keller, A.S. Sweet, The Reception of the ECtHR in National Legal Orders, in: H. Keller, A.S. Sweet (eds.), A Europe of Rights: The Impact of the ECtHR on National Legal Systems, Oxford - New York, 2008, p. 1.

${ }_{29}$ Parliamentary Assembly of the Council of Europe, Resolution No. 2075 (2015) on Implementation of Judgments of the European Court of Human Rights, available at: http:/ / assembly.coe.int/nw/xml/XRef/Xref-XML2HTML-en.asp?fileid=22197\&lang=en; See also A. Szklanna, Ochrona prawna cudzoziemca w świetle orzecznictwa Europejskiego Trybunatu Praw Człowieka, Instytut Wydawniczy EuroPrawo, Warszawa, 2010, p. 304.

${ }^{30}$ J. Lapitskaya, ECtHR, Russia, and Chechnya: Two Is Not Company and Three Is Definitely a Crowd, 43(2) "International Law and Politics" 2011, vol. 43, issue 2, p. 480; P. Leach, Strasbourg's Oversight Of Russia: An Increasingly Strained Relationship, "Public Law" 2007, issue 4, pp. 640-654.

${ }^{31}$ C. Hillebrecht, Implementing International Human Rights Law at Home: Domestic Politics and the European Court of Human Rights, "Human Rights Review" 2012, vol. 13, issue 13, p. 288.

${ }^{32}$ V. Starzhenetskii, Assessing Human Rights in Russia: Not to Miss the Forest for the Trees. A Response to Preclik, Schönfeld and Hallinan, in: L. Mälksoo (ed.), Russia and European human-rights law: the rise of the civilizational argument, Leiden, 2014, pp. 210-211. 
resolutions and recommendations of the Parliamentary Assembly and the Committee of Ministers ${ }^{33}$. There are various reasons behind non-implementation. The Parliamentary Assembly in its resolution of 28 September 2000 identified seven of them: political reasons, reasons to do with the reforms required, practical reasons relating to national legislative procedures, budgetary reasons, reasons to do with public opinion, judgments which are casuistical or unclear, and reasons relating to interference with obligations deriving from other institutions ${ }^{34}$. However, the most "dangerous" reason for the Convention protection system, even though not explicitly mentioned in the 2000 PACE resolution, is when state authorities unequivocally reject implementation of a Strasbourg judgment (sanction of denial) ${ }^{35}$, usually because of its alleged contradiction with the basic principles of domestic law. It concerns especially the countries, whose hierarchy of legal norms places international law below their constitutions, and which, on the other hand, treat the Convention law as self-executing ${ }^{36}$. In such situations, national constitutional or other supreme courts have played a key role in establishing the relation between the Convention and domestic law. Most of them also have given legal priority to the constitution over the Convention (including its article 46 regarding the obligation to implement the ECtHR's verdicts). The German Constitutional Court's judgment in the case of Görgülü̈ (regarding the

${ }^{33}$ I. Wrońska, Fundamental rights protection in the Council of Europe: the role of the European Court of Human Rights, "Temida 2", Białystok, 2011, pp. 148 and the following.

${ }^{34}$ Parliamentary Assembly of the Council of Europe, Resolution 1226 (2000) on Execution of judgments of the European Court of Human Rights, point 8, available at: http:/ / assembly.coe.int/nw/xml/XRef/Xref-XML2HTML-EN.asp?fileid=16834\&lang=en.

${ }^{35}$ Michał P. Kaszubski, Reakcja sądów krajowych na dynamiczna wykładnię prawa międzynarodowego, in: Anna Wyrozumska (ed.), Granice swobody orzekania sądów, Łódź 2014, p. 254, available at: https://www.wpia.uni.lodz.pl/files/chairs/7/publikacje/ Anna_Wyrozumska_red_Granice_swobody_orzekania_sadow_miedzynarodowych.pdf.

${ }^{36}$ This is the case of most Council of Europe members; see A. Peters, Supremacy Lost: International Law Meets Domestic Constitutional Law, "Vienna Online Journal on International Constitutional Law" 2009, issue 3, p. 192. The exceptions are e.g. Spain, which gives the Convention the status of constitutional law and, especially, the Netherlands, where the treaty even prevails over the domestic fundamental law. In a broader perspective, this concerns the fundamental issue of relation between the international and domestic (especially constitutional law).

${ }^{37}$ Entscheidung des Bundesverfassungsgerichts (ruling of German Constitutional 
domestic courts decisions on child custody issue, for which the ECtHR had found violation of Article 8 of the Convention ${ }^{38}$ ) may serve as a good example. Although the German court emphasised a duty of fulfilment of obligations stemming from the Convention, including implementation of the ECtHR's verdict, it nevertheless stated, that "[t]ake into account" means taking notice of the Convention provision as interpreted by the ECtHR and applying it to the case, provided the application does not violate prior-ranking law, in particular constitutional law" (point 63 of the judgment). ${ }^{39}$ The judgment by the German Constitutional Court stood in line with its previous jurisprudence regarding the relation of German Fundamental Law and the European Union law (Solange cases). A similar position towards either the Convention or EU law was adopted by many other national constitutional or supreme courts across Europe, inter alia France, Italy, Austria, Lithuania, Poland, the Czech Republic, Slovakia etc. ${ }^{40}$ On the other hand, the ECtHR is of the view that it is competent to review the conformity of domestic constitutions' provisions with the Convention law. ${ }^{41}$ Apart from the basic pacta sund servanda argument, it has been emphasised that the Convention provisions are of a constitutional character. ${ }^{42}$

Court), dated 14 October 2014, 1481/04 (Görgülü) 111 BVerfGE 307; English translation available at: http://www.bundesverfassungsgericht.de/SharedDocs/Entscheidungen/ EN/2004/10/rs20041014_2bvr148104en.html;jsessionid=889B945D4059027F698901866 5FD8478.2_cid394.

38 ECtHR, Görgülü v. Germany (74969/01), judgment of 26 February 2004.

39 More on the topic see F. Hoffmeister, Germany: Status of European Convention on Human Rights in domestic law, "International Journal of Constitutional Law 2006", volume 4, issue 4, pp. 722-731.

40 A. Peters, supra note 36.

${ }^{41}$ Apart from the above mentioned Anchugov and Gladkov v. Russian Federation case, see i.a. Kulinski and Sabev v. Bulgaria (63849/09), judgment of 21 July 2016 (similarly, regarding constitutional blanket ban on voting rights of prisoners), Alajos Kiss v. Hungary (38832/06), judgment of 20 May 2010, (regarding limiting of voting rights for persons with partial guardianship).

42 ECtHR (Grand Chamber), Loizidou v. Turkey (40/1993/435/514), judgment of 23 March 1995, § 75; see also Giorgio Malinverni, "The Status of Human Rights Treaties in Domestic Legal Systems", in: Venice Commission, The Status of International Treaties on Human Rights, (Series "Science and technique of democracy", no. 42), (Council of Europe Pub., Strasbourg, 2006), 148. 
Similar problems with adherence to the Convention law may occur when the treaty is not directly applicable in the domestic legal order, with the UK as a primary example. As it was mentioned earlier, the country's problem with non-implementation of the ECtHR's verdicts also developed on the basis of the deprivation of the voting rights of prisoners. In its rulings in the cases of Hirst (No 2) v. UK $K^{43}$ and Greens and MT $v U^{4}{ }^{44}$, the Strasbourg Court decided that a blanket ban regarding voting rights of prisoners in the UK violated Article 3 of Protocol No 1 to the Convention. In spite of it, on 16 October $2013^{45}$, the UK Supreme Court dismissed the appeals of George McGeoch and Peter Chester, prisoners serving life sentences for murder, who had brought domestic law proceedings challenging the ban. The judges used the arguments related to the concept of "judicial dialogue", which - in their opinion allowed British courts to not follow "simple Chamber decisions" in order for the ECtHR to know "domestic" arguments better and thus to review its viewpoint on specific matters. However, it was pointed out that "[i]t would have then to involve some truly fundamental principle of our law or some most egregious oversight or misunderstanding before it could be appropriate for this Court to contemplate an outright refusal to follow Strasbourg authority at the Grand Chamber level" (point 27 of the Supreme Court's ruling). Despite subsequent ECtHR's judgments regarding prisoners' voting rights ${ }^{46}$, none of them has been implemented by the UK, which is also a continuous point of concern within Council of Europe institutions. ${ }^{47}$

${ }^{43}$ ECtHR (Grand Chamber), Hirst (No 2) v. UK (74025/01), judgment of 6 October 2005.

${ }^{44}$ ECtHR, Greens and MT v UK (60041/08 \& 60054/08), judgment of 23 November 2010.

${ }^{45}$ UK Supreme Court, Judgment of 16 October 2013 in the case of Chester v. Secretary of State for Justice, McGeoch v.The Lord President of the Council, [2013] UKSC 63.

${ }^{46}$ See more on this topic: A. Wyrozumska, Prawotwórcza działalność sądów międzynarodowych i jej granice, in: A. Wyrozumska, Granice swobody orzekania sądów międzynarodowych, supra note 35, pp. 66 and following.

${ }^{47}$ E.g. Committee of Ministers of Council of Europe, Interim Resolution CM/ResDH (2015) 251 on Execution of the judgments of the European Court of Human Rights Hirst and three other cases against the United Kingdom, available at: https:/ / search.coe.int/cm/Pages/ result_details.aspx?ObjectID=09000016805b149e. 


\section{RUSSIA- YET ANOTHER EXAMPLE OF "JUDICIAL DIALOGUE"?}

Does it mean that the above-mentioned recent $\mathrm{RCC}^{\prime}$ s verdicts should be treated as just another example of "judicial dialogue" or is there more behind it? A few aspects should be taken into account in this respect. Firstly, one should bear in mind the specific tension that has for a long time been characteristic of Russia's history and culture and thus influenced also its legal order. The country's identity has been in fact 'torn' between two competing philosophical as well as political ideas: the liberal approach (Westernism, Rus. zapadnichestvo) and a "native" one (slavophilia, rus. slavyanofil'stvo) ${ }^{48}$. Additionally, the issue of human rights was completely negated during the Communist period and the process of introducing them to the newly established democratic system has met with serious problems ${ }^{49}$.

When Russia accessed the Council of Europe in 1996, soon after the collapse of the totalitarian regime, and ratified the Convention two years later, it was regarded as a pro-Westernism step towards the implementation of a "western", individual-oriented concept of human rights ${ }^{50}$, together with accepting the supremacy of the latter. However, in reality, that did not change the overwhelming "sovereignty" position of the Russian legal doctrine and jurisprudence regarding the relation between domestic (especially constitutional) and international law, and human rights constituted no exception in this matter ${ }^{51}$. In theoretical terms, such an approach was described as a "securitization" (of domestic legal tradition) against at least partly strange, "non-native" ideas ${ }^{52}$. In the

${ }^{48}$ J.H. Billington, Icon and Axe: an Interpretative History of Russian Culture, Vintage, 2010, e-book, infra.

${ }^{49}$ See, e.g. E. A. Lukasheva, Prawa człowieka a tworzenie państwa prawa w warunkach reformowania ustroju politycznego i gospodarczego Rosji, 4 “Toruński Rocznik Praw Człowieka i Pokoju" 1996, pp. 20 and following.

${ }^{50}$ L. Mälksoo, Russian approaches to international law (Oxford University Press, Oxford, 2015), 160.

51 Ibidem, pp. 123 and following.

52 Petr Preclik, "Culture Re-introduced: Contestation of Human Rights in Contemporary Russia", in: Russia and European human-rights law: the rise of the civilizational argument, L. Mälksoo (ed.), (Brill Nijhoff, Leiden, 2014), and following. 
wider perspective, the concept of the "organic" modernisation of law (which included drawing some legal ideas from the West, but based on national legal tradition gained much popularity ${ }^{53}$. Thus, as mentioned before, the issue of constitutional supremacy was raised even before the recent RCC judgments, as it was in relation to the above-mentioned case of Markin v. Russia, regarding discrimination in parental leave on grounds of sex ${ }^{54}$. After the 2010 ECtHR's judgment ${ }^{55}$, in which the RCC's affirmative position on that matter was rejected, the President of the latter wrote a highly critical article in a daily newspaper, in which he warned that if "the historical, cultural and social situation" was to be further ignored by the ECtHR, Russia might be forced, in the future, to ignore judgments of the Strasbourg Court. ${ }^{56}$

Besides, there are more specific arguments to the point that the recent Russian law and jurisprudence regarding implementation of ECtHR's judgments in some aspects vary from the other CoE countries, in which a similar process or at least similar legal arguments had appeared. Firstly, it should be emphasised that the substantial scope of the review of the ECtHR's judgments by the RCC is significantly broad, as it covers any provision of the Russian Constitution, as interpreted by the latter. In fact, although the RCC in its latest judgments noted that rejecting the implementation of the Strasbourg Court's ruling "may take place in exceptional cases and in the presence of sufficiently weighty reasons (...)" (point 2 of the RCC's judgment of 19 January 2017, point 4 of the RCC's judgment of 14 July 2015), one may wonder what was so exceptional in the case of Yukos v. Russia. The case concerned the violation of the right to property, definitely not the most important one within either the

${ }^{53}$ J. Kowalski, Konstytucja Federacji Rosyjskiej a rosyjska i europejska tradycja konstytucyjna, Warszawa-Poznań 2009, pp. 181-182. In that aspect, the specific situation of Russia, including the size of the country, its demography, traditional values, transitional economy, as well as problems related to terrorism, separatism etc. is usually mentioned.

${ }^{54}$ Supra note 14.

55 ECtHR (Grand Chamber) Konstantin Markin v. Russia (30078/06), judgment of 22 March 2012 (the Chamber delivered a judgment on 7 October 2010).

56 V. Zorkin, Predel ustupchivosti, "Rossiiskaia gazeta" (29 October 2010), as cited by L. Mälksoo, in his "Introduction" to Russia and European human-rights law: the rise of the civilizational argument (supra note 52, p. 5). It was actually then when the first (yet unsuccessful) political steps were taken in order to introduce undermining mechanism of the ECtHR's verdicts. 
Convention or constitutional law, and the other constitutional right, that would be allegedly "breached" if executing the ECtHR's verdict (according to the Russian judges) was equality in the aspect of taxation duties. It is hard to accept that even a very significant amount of compensation may make the case "exceptional".

I am also of the view that, as to the countries in which international treaties are placed in the hierarchy of legal norms below a constitution, it is in fact legally justifiable to deviate from an international obligation if the latter contradicts provisions of the constitution - especially, as in the case of Russia or Poland, where the fundamental laws were adopted in democratic, nation-wide referenda. In that sense I agree with the reasoning of the above-mentioned highest national courts. I argue however, that the situation of collision with international law must take place only in truly exceptional situations, or, as the UK Supreme Court stated (as cited above) "[i]t would have then to involve some truly fundamental principle of our law or some most egregious oversight or misunderstanding $(\ldots)^{\prime \prime}$. Obviously, it is extremely difficult to judge which situation may be called truly exceptional. Regarding the said 2013 UK Supreme Court's judgment, to my mind it can hardly be accepted that the banning of the voting rights of prisoners may constitute a "truly fundamental principle" of any European country's law. The idea of "multipolar fundamental rights relations", i.e. the situation when one human right is weighted against another, as indicated by the German Constitutional Court ${ }^{57}$, may be useful - but only to some extent, because, as may be seen from the latest RCC's judgment regarding the case of Yukos, the scope of the values, which may be put on the other scale, can be alarmingly broad, including the (very general) right to equality in tax burdens. Nevertheless, I argue that at least in the Polish reality such a case could happen if the Strasbourg Court hypothetically indicated in its ruling as a general measure an obligation to liberalize the current Polish legislation regarding abortion. In such a case, however, there would be the issue of the non-derogable right to life (including of the unborn) on the scale,

${ }^{57}$ Entscheidung des Bundesverfassungsgerichts (ruling of the German Constitutional Court), dated 14 October 2014, 1481/04 (Görgülü), op. cit. note 37. See also A. Müller, The ECtHR and German and Russian Courts, in: A. Müller, H.E. Kjos (eds.), Judicial Dialogue and Human Rights, New York 2017, p. 325. 
indeed the most fundamental principle of our law, as confirmed by the Constitutional Court in the judgment of 27 May 1997.58

On the other hand, bearing in mind that the UK Supreme Court's words related to the Grand Chamber's judgments, it must be regretted that the ECtHR did not grant leave to appeal for Russia as for its 2014 judgment in the case of OAO Neftyanaya Kompaniya Yukos v. Russia. Delivering judgment by the Grand Chamber would definitely strengthen "pressure" for its implementation, especially bearing in mind that the judges in the Chamber's judgments were split in voting (4:3 in the 2011 judgment, 5:2 in the 2014 judgment). The "serious question affecting the interpretation or application of the Convention or the Protocols thereto", required for referral of the case to the Grand Chamber under Article 43 sect. 2 of the Convention could cover the unclear status of victims of the violation and take into account the responsibility of shareholders regarding the conduct of a company's management board when ruling on awarding just satisfaction (for details, see dissenting opinion of judges Bushev and Hajiyev to the 2014 judgment).

The other aspect of Russian specificity is related to the issue of binding interpretation of the Convention law made by the ECtHR pursuant to Article 46 of the Convention, which is in fact questioned by the RCC, since the latter, referring to the respective articles of the Vienna Convention on the Law of Treaties, stated in its last judgments, that a state is competent to decide whether the Strasbourg Court, while

"interpreting in the course of consideration of a case any provision of the Convention for the Protection of Human Rights and Fundamental Freedoms, provisions of which are highly abstract, attributes to a term used in it another meaning than its usual one or carries out interpretation contrary to the object and purpose of the Convention as a whole".

In such a situation, the state "in whose respect the judgment in this case has been delivered is entitled to refuse to execute it as going beyond the obligations, voluntarily taken upon itself when ratifying the Convention" (point 2 of the RCC's judgment of 19 January 2017, see also point 3 of the RCC's judgment of 14 July 2015). In my opinion, although

${ }^{58}$ Decision of the Polish Constitutional Tribunal of 28 May 1997, no. K. 26/96, OTK ZU No. 2/1997, item 19, point 4.3. 
one has every right to criticize the ECtHR's verdicts on various grounds, it is not legally possible, in the context of the clear text of Article 46 of the European Convention of Human Rights, to reject the Strasbourg Court's power to give a binding interpretation of the Convention regarding the respondent state. Such an approach is specific only to the RCC, as the other above-mentioned highest national courts only elaborated on the conformity of the ECtHR's judgments with the domestic law.

Quite specific to the RCC is also its attitude towards the possible reconciliation between the Russian Constitution, as interpreted by the RCC, and the Convention law, as interpreted by the ECtHR. It was visible especially in the former's judgment regarding the implementation of the ruling of the latter in the case of Anchugov and Gladkov v. Russian Federation. In the reasoning of the RCC, the only way to stay in conformity with the ECtHR's judgment consisted is the suggestion that

"[a]t the same time the federal legislator is not deprived of the possibility, consistently realizing the principle of humanism in the criminal law, to optimize the system of criminal penalties, including by means of transfer of individual regimes of serving deprivation of liberty to alternative kinds of penalties, although connected with forced restriction of liberty of convicted persons, but not entailing restriction of their electoral rights" (point 5.5. of the RCC's judgment of 19 April 2016).

Such an approach contrasts e.g. with the position of the Polish Constitutional Court, which, when ruling on the unconstitutionality of the implementation of the European Council's framework decision on the European Arrest Warrant ${ }^{59}$, suggested the need to alter the Constitution (a suggestion that was later applied by the legislative) - something that the RCC did not even hint about.

Last, but not least, one may argue that the whole review procedure of the constitutionality of the implementation of ECtHR's judgments is quite disturbing, not only even because there is nothing analogous in other CoE countries, but also because of its substance. As the Venice Commission put it, it is an "all or nothing" procedure, with only two

59 Decision of the Polish Constitutional Tribunal of 27 April 2005, OTK ZU No. 4/A/2005. Similar suggestion was contained in the Judgment of the German Constitutional Court, dated 18 July 2005, no. 2236/04, 113 BVerfGE 273. 
possible conclusions - either a decision on constitutionality, or on the absolute impossibility of the implementation of the verdict reviewed ${ }^{60}$. Thus, there is no room for dialogue between the executive power (responsible for the implementation) and the constitutional court on different possible methods and ways of execution, which would reconcile the need to adhere to international law with constitutional provisions. Paradoxically, in the countries which also accept the supremacy of their constitutions, but without any formal review procedure established, the highest courts retain more flexibility in order to reconcile the domestic law with the ECtHR's verdicts, something which should definitely be their priority task and aim.

\section{CONCLUSIONS}

Alas, judging the recent approach of the Russian judicial authorities towards the implementation of ECtHR's judgments is definitely a complicated issue. The RCC calls it another example of judicial dialogue and one may not disregard the arguments standing behind such an approach, especially taking into account the position of other domestic highest courts. However, even excluding the political context of the Yukos case, the specificity of the Russian approach is also visible and at least partly disturbing. The most important question is whether the RCC will indeed limit itself to "exceptional" situations, in which nonimplementation is justified because of a "truly fundamental principle" of domestic constitutional law. In the case of OAO Neftyanaya Kompaniya Yukos v. Russia it definitely failed to do so and, thus, the prognosis is rather pessimistic.

${ }^{60}$ European Commission for Democracy through Law (Venice Commission), supra note 18 , point 32 . 